\title{
Urgensi Menulis Bagi Mahasiswa: Refleksi atas Mata Kuliah Penulisan Naskah Dakwah
}

\author{
Muridan"
}

"Penulis adalah Magister Agama, Dosen Tetap Junusan Dakwah STA/N Purwokerto

Abstract: Dakwah basically is changing one situation to a better situation. Besides by oral media, dakwah also delivered with witten media. Nowadays, dakwah with witten media is a must. There's many media that can be used, several are books, joumal, newspaper, magazine, tabloid, bulletin, etc. the better feature of witten media are can be read many times and also can reach many audience. Therefore, remembering importance of dakwah activity through witten media, there's a lesson especially for dakwah student, namely dakwah text witing lecture. Keywords: dakwah, media, witten media, dakwah text witing.

\section{PENDAHULUAN}

Dakwah, pada hakikatnya, adalah menerjemahkan kepercayaan ajaran Islam ke dalam kehidupan pribadi, kehidupan keluarga, kehidupan sosial, politik, ekonomi, serta budaya secara totalitas. ${ }^{1}$ Menerjemahkannya ke dalam komunikasi yang efektif menjadi tugas seluruh umat Islam, baik laki-laki maupun perempuan. ${ }^{2}$ Dalam menyampaikan atau mempresentasikan dakwah ini harus dilakukan secara baik, rendah hati, arif dan santun, serta melalui bahasa yang efektif. ${ }^{3}$ Hal ini menjadi penting, agar ajaran Islam dapat diterima dengan mudah oleh masyarakat.

Dakwah dapat dilakukan melalui dua bahasa, yakni bahasa lisan dan tulisan. Secara kuantitatif para dai yang berdakwah melalui tulisan jauh lebih sedikit dibandingkan dengan yang menggunakan bahasa lisan. Oleh karena itu, tulisan ini dititikberatkan pada dakwah menggunakan bahasa tulisan. Tulisan, khususnya media massa cetak, kalau kita perhatikan di zaman sekarang ini, banyak sekali media massa cetak yang dapat dijadikan sebagai media dakwah, seperti majalah, koran, jurnal, buku, tabloid, bulletin, dan lain-lain. Seharusnya, hal ini merupakan lahan empuk dan menjanjikan bagi mahasiswa, khususnya dalam mengembangkan krteativitas menulis mereka, terlebih mereka adalah merupakan agen of change bagi masyarakat.

\section{KONSEP KEPENULISAN DALAM ISLAM}

Perintah untuk menulis di dalam al-Qur'an memang banyak, tetapi jika dibandingkan dengan perintah untuk membaca, berfikir, dan menggunakan akal secara kuantitatif jumlahnya lebih sedikit. Sedikitnya, perintah menulis, bukan berarti kegiatan menulis menjadi tidak penting. Sebaliknya, sedikitnya perintah menulis itu seharusnya lebih memotivasi umat Islam untuk lebih giat menulis sebagaimana yang dilakukan oleh ulama-ulama besar dahulu seperti Imam al-Ghazali.

Kalau kita telusuri, perintah menulis di dalam al-Quran terdiri dari tiga akar kata, yaitu kata pena (qalam), kata tinta (Midad), dan menulis (kataba). ${ }_{4}$ Kata-kata pena selalu dirangkai dengan kalimat Tuhan yang berarti Ilmu Tuhan dan katakata menulis. Dari ketiga kata ini, dapat ditarik benang merahnya bahwa ilmu Allah itu sangatlah luas dan tidak akan habis walaupun ditulis secara terus-menerus oleh semua manusia.

Jika seluruh umat manusia mau menulis, maka Ilmu pengetahuan akan terus berkembang sampai akhir zaman. Mengingat begitu urgennya kegiatan tulis-menulis bagi perkembangan dan kemajuan ilmu pengetahuan, maka tidak dibenarkan jika umat Islam menganggap ringan persoalan tulis-menulis. Satu hal yang perlu digaris bawahi adalah secara 


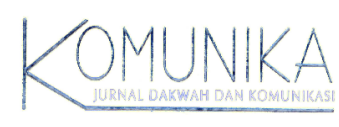

eksplisit memang dasar-dasar normatif Islam untuk menulis ini kurang memotivasi bagi tumbuhnya budaya menulis. Berbeda dengan dasar normatif Islam dalam hal menghafal. Ini dibuktikan dengan banyaknya Hadis yang menyebutkan barangsiapa yang menghafalkan al-Qư’an, maka malaikat akan mendoakannya setiap saat. Barangsiapa yang menghafalkan empat puluh Hadis, maka akan dikategorikan syuhada. ${ }^{5}$

\section{SEJARAH KEPENULISAN DALAM ISLAM}

Persoalan tulis-menulis, dalam dunia Islam, memang bukanlah hal baru. Dalam bentangan sejarah perjalanan Islam, kita selalu melihat adanya keterkaitan antara kegiatan tulis-menulis dengan perkembangan ilmu pengetahuan. Untuk melihat seberapa besar motivasi dan semangat kepenulisan dalam Islam, kita perlu melihat kembali sejarah pemikiran-pemikiran Islam yang ditulis pada buku-buku keislaman.

Kegiatan tulis-menulis sebenarnya telah dimulai sejak rasul masih hidup. Setiap wahyu turun, rasul memerintahkan sahabat-sahabatnya untuk langsung menulis, walaupun pada masa itu masih ditulis di pelepah-pelepah kurma. Pasca rasulullah meninggal, kegiatan tulis-menulis ini terus berkembang, bahkan pada masa Khulafaurrasyidin, Abu Bakar menghimpun ayat-ayat al-Quran yang masih berserakan untuk dikumpulkan dan ditulis kembali untuk kemudian dibukukan. ${ }^{6}$

Semakin lama, kegiatan tulis-menulis semakin menggugah masyarakat sehingga bermunculanlah ilmu-ilmu baru seperti seperti kimia, kedokteran, optik, ilmu fiqh, dan lain-lainnya. Tradisi ini selain bertujuan untuk mengembangkan ilmu pengetahuan dan teknologijuga untuk melestarikan ajaran Islam.

Sungguh ironis, jika tradisi besar dan hebat yang seharusnya terus dijaga dan dikembangkan, ternyata berhenti seiring runtuhnya kejayaan karya-karya besar ulama terdahulu. Banyak umat Islam yang mencukupkan diri dengan karya-karya besar sebelumnya, dan merasa takut untuk berijtihad. Dalam kondisi seperti ini, jelaslah bahwa dinamika ilmu-ilmu keislaman mengalami kemacetan total karena tanpa karya-karya besaryang berbobot terlahirkan.

\section{BENTUK-BENTUK PENULISAN NASKAH DAKWAH}

Berbicara tentang penulisan naskah dakwah, Ircham Mc., membagi dalam dua bentuk.7 Pertama tulisan ilmiah, yaitu karangan ilmiah yang ditulis dengan menggunakan bahasa baku. Termasuk ke dalam tulisan ilmiah ini adalah: makalah, penelitian, dan juga buku. Sebuah naskah dapat dikatakan sebagai ilmiah jika di dalamnya terdapat kerangka sebagai berikut: (1) terdapat judul, (2) nama penulis, (3) Abstrak, (4) pendahuluan, (5) batang tubuh tulisan atau karangan, (6) kesimpulan dan saran, serta (7) referensi dan lampiran. ${ }^{8}$

Dari kerangka di atas, sebuah tulisan ilmiah tidak harus meliputi semuanya, setidaknya ada enam dari delapan kerangka tersebut terpenuhi yaitu terdapat judul' nama penulis, pendahuluan, batang tubuh, kesimpulan dan referensi. Kedua adalah adalah ilmiah popular, tulisan ilmiah popular adalah sebuah karangan atau tulisan yang tidak terlalu panjang dan nonfiksi dan bukan cerpen. ${ }^{9}$ Dikatakan ilmiah karena tulisan tersebut harus dapat dipertanggungjawabkan kebenarannya, objektif dan bukan subjektif. Popular karena sifatnya akrab, menyenangkan bagi pembaca umum karena bahasanya yang mudah dipahami.

Menurut Ari Suseno, dalam penulisan naskah ilmiah popular, ada delapan kerangka yang harus dipenuhi, yaitu: (1) memilih topik: memilih topik adalah memilih pokok pembicaraan atau pokok permasalahan yang akan disorot. Topik ini bisa sosial, politik ekonomi, budaya, dan juga agama; (2). menentukan tema: tema merupakan penyempitan dari topik. Tema merupakan pikiran dasar landasan cerita atau pokok pikiran yang mendasari suatu karangan atau tulisan yang akan dijabarkan dari awal sampai akhir; (3) mengumpulkan bahan: bahan untuk penulisan ilmiah popular ini dapat dikumpulkan dari buku, majalah, koran, makalah, wawancara dengan pakar, observasi, maupun penelitian; (4) membuat judul: judul memang tidak harus ditulis dari depan, judul dapat ditulis ketika kegiatan menulis telah selesai. Membuat judul di depan hanya berfungsi untuk memberi arah yang lebih jelas pada tulisan yang akan dibuat; (5) memilih pola penggarapan: setidaknya ada lima hal yang perlu diperhatikan dalam pola penggarapan tulisan ilmiah popular, yaitu: pola pemecahan 
masalah, pola pendapat dan alasan pemikiran, pola kronologi, pola pembandingan dan pola abstraksi - deskripsi. Pada praktiknya, tidak dipakai semuanya, tetapi dapat diambil tiga atau empat pola saja sesuai dengan kebutuhan. Melalui langkahlangkah inilah koordinasi bahan-bahan dan gagasan-gagasan akan dituangkan; (6) membuat outline: outline berfungsi untuk menuntun pada sistematika penulisan, mengingatkan aspek mana saja yang akan dibahas sesuai dengan tema yang digarap; (7) memulai atau membuka karangan: memulai sebuah tulisan adalah suatu yang sulit. Untuk memudahkannya dapat menggunakan intro-statement, intro abstraksi, intro analogi, intro narasi, intro deskripsi, intro cuplikan, ataupun intro pertanyaan. Intro ini dapat dipilih sesuai dengan selera penulis, tema yang diangkat, dan media yang akan dikirimi; (7) membangun serta menutup karangan..$^{10}$ Membangun karangan, pada dasarnya, adalah menyusun kalimat, alinea, gagasangagasan, argumentasi, dan analisis sesuai dengan tema penggarapan sampai karangan berakhir dan ditutup."

Satu hal yang perlu di perhatikan bahwa tulisan ilmiah popular bukanlah tulisan yang akan dikonsumsi oleh diri sendiri, tetapi untuk dikonsumsi publik. Oleh karena itu, daya komunikasi, daya tarik daya keenakan baca sangat penting diperhatikan.

\section{PENULISAN NASKAH DAKWAH}

Naskah dakwah, pada dasarnya, adalah naskah keislaman. Naskah ini dapat ditulis dalam dua model, yaitu model ilmiah murni dan juga ilmiah popular. Pada prosesnya, antara keduanya sebenarnya tidak jauh berbeda. Kalaupun ada hanya pada hal-hal yang bersifat teknis saja. Perbedaan yang mutlak terdapat pada kebebasan mutlak dan kebebasan terbatas. Pada penulisan ilmiah popular, ajaran Islam dapat ditafsirkan secara bebas dan mengikuti penafsiran yang beraneka macam. Walaupun demikian, dalam ajaran Islam terdapat nilai-nilai yang absolute, yang harus tetap dijaga dan tidak boleh dilanggar. ${ }^{12}$

Untuk menulis naskah dakwah, perlu didipahamijuga ruang lingkup cakupannya. Menulis naskah dakwah bukan hanya terbatas pada aspek ibadah saja. Oleh karena Islam tidak hanya berbicara masalah ibadah ritul, surga- neraka, pahala dan dosa, kafir dan muslim, al-Qur'an dan al-Hadis, tetapi sangatlah luas meliputi berbagai aspek kehidupan seperti sosial, politik, budaya, ekonomi, danjuga teologi.

Ada dua bentuk naskah dakwah, yaitu: pertama, naskah yang hanya memiliki misi dakwah islamiah yang menyejukan. Biasanya, naskah seperti ini, bersifat deskriptif, dan tidak banyak disertai analisis kritis. Bentuk tulisan seperti ini biasanya untuk konsumsi masyarakat awam. Target yang dituju adalah menciptakan kesejukan, ketenangan, pengisian kembali nilainilai spiritual dalam batin pembacanya. Dalil-dalil berupa nash-nash al-Qur'an maupun al-Hadis, serta latar belakang historis pada naskah ini menjadi penting. Hal ini untuk meyakinkan pembaca awam. Kedua, adalah bentuk naskah yang mencerdaskan umat. Bentuk naskah kedua ini biasanya lebih mengedepankan penafsiran-penafsiran data secara akurat dan kritis. Tujuannya adalah mencerdaskan umat dengan menitikberatkan pada dialog intelektual, serta mengedepankan ide-ide baru dengan argumentasi yang orisinil.13 Dalam bentuk naskah kedua ini, antara data dan analisis harus seimbang, bahkan diperlukan prediksi-prediksi teoretis yang cocok untuk masa depan.

Walaupun ada perbedaan di dalam kedua model penulisan nasklah tersebut, tetapi langkah-langkah yang harus ditempuh tetap sama, yakni butuh data akurat yang dapat dicek kebenarannya, memiliki pandangan yang luas dan kritis.

\section{URGENSI KEPENULISAN BAGI MAHASISWA}

Kampus sebagai salah satu lumbung pemikiran, ternyata tradisi tulis-menulisnya masih rendah jika dibandingkan dengan tradisi lisannya. Kuatnya tradisi lisan ini menyebabkan kampus terasa miskin dengan karya-karya dan publikasipublikasi ilmiah. Hanya beberapa orang saja, baik mahasiswa maupun dosen, yang tetap memiliki perhatian besar pada dunia tulis-menulis dan pemikiran. Hal ini pun jika dipersentasekan masih tidak seimbang antara jumlah mahasiswa dan dosen dengan karya-karya yang dihasilkannya.

Bagi mahasiswa, aktivitas menulis seharusnya menjadi suatu yang urgen karena menulis itu memiliki banyak manfaat. Pertama, menulis dapat dijadikan sebagai sarana untuk membangun kecerdasan intelektual. Bagi mahasiswa, menulis, sebenarnya, adalah suatu yang murah dan mudah, mengingat sarana yang dibutuhkan tidak terlalu sulit untuk dicapai seperti perpustakaan, buku, majalah, surat kabar, jurnal, dan internet karena mudah diperoleh di lingkungan kampus. ${ }^{4}$ Kedua, 


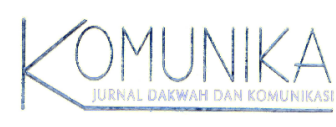

menulis akan mendatangkan keuntungan berupa honorarium. Jika sebuah tulisan di muat di sebuah media massa, tentu akan mendapatkan honorarium dari media tersebut. Di zaman sekarang, honor menulis cukup menggiurkan. Ketiga, dengan menulis segala unek- unek dalam hati akan terbebaskan dan akan menimbulkan kepuasan di dalam hati. Kepuasan adalah sesuatu yang sangat berharga, yang tidak dapat ditukar dengan nilai nominal apapun. Keempat, menulis berarti mendidik diri sendiri dan masyarakat. Dengan menulis berarti ikut membantu memberikan sesuatu yang bermanfaat kepada masyarakat yang jumlahnya cukup banyak. Kelima, menulis dapat membuat nama seseorang menjadi terkenal (popular), terlebih jika menjadi penulis yang kreatif dan produktif.

Begitu urgennya aktivitas tulis-menulis ini, maka perlu kiranya mewujudkan gagasan menjadikan menulis sebagai sebuah profesi. Dengan begitu, diharapkan akan semakin banyak mahasiswa yang menggeluti profesi itu.

\section{STRATEGI PEMBELAJARAN TEKNIK PENULISAN NASKAH DAKWAH BAGI MAHASISWA}

Ada beberapa strategi yang dapat dikembangkan dosen untuk mata kuliah “Teknik Penulisan Naskah Dakwah”, salah satunya adalah dengan pembelajaran kontektual. ${ }^{5}$

Proses pembelajaran ini: pertama, adalah dengan pembelajaran berbasis masalah. Melalui strategi ini, mahasiswa diminta untuk mencatat permasalahan-permasalahan aktual dan kontektual yang sedang ramai dibicarakan di masyarakat. Selanjutnya, mahasiswa dirangsang untuk berpikir kritis, menganalisis sekaligus mencari jalan keluar atas permasalahan tersebut dan kemudian dituangkan dalam bentuk naskah, baik ilmiah murni maupun ilmiah popular. Selanjutnya, naskah tersebut didiskusikan di dalam kelas.

Kedua, adalah dengan membuat aktivitas belajar mandiri. Mahasiswa merupakan sosok yang telah mampu berpikir kritis, mampu mencari, menganalisis, dan mengolah informasi tanpa bantuan dosen. Oleh karena itu, dalam pengalaman belajar kontekstual diperlukan uji coba terlebih dahulu: di sini mahasiswa diberikan waktu yang cukup untuk menyusun kerangka penulisan tanpa meminta bantuan dosen supaya dapat melakukan belajar secara mandiri (independent learning).

Ketiga, adalah dengan memanfaatkan lingkungan mahasiswa untuk memperoleh pengalaman belajar. Untuk memperkaya wawasan, dosen boleh memberikan tugas kepada mahasiswa yang dapat dilakukan di berbagai konteks lingkungan, baik kampus maupun masyarakat. Tugas ini dimaksudkan untuk memberikan kesempatan kepada mahasisewa di luar perkuliahan. Misalnya, mahasiswa dapat berwawancara langsung dengan orang-orang yang sudah terbiasa menulis, baik tulisan ilmiah murni seperti buku, jurnal penelitian, maupun tulisan ilmiah popular seperti pada koran, majalah maupun tabloid.

\section{KESIMPULAN}

Indonesia dalah Negara yang kaya akan khazanah budaya, pemikiran, agama, maupun keunikan sejarah. Ironisnya, orang Indonesia sendiri kesulitan untuk mengetahuinya. Hal ini terjadi karena miskinnya data-data tertulis yang terdokumentasi dengan baik sehingga, ketika ingin mengetahui Indonesia, harus pergijauh ke negeri Belanda.

Kesulitan ini sebenranya bukan terjadi karena kebodohan masyarakat Indonesia, tetapi lebih pada kemalasan masyarakat Indonesia untuk menulis tentang dirinya, agamanya, lingkungan, dan budayanya sendiri. Akibatnya, budaya yang muncul di masyarakat lebih suka untuk menjadi konsumen bagi karya-karya bangsa lain.

Lemahnya budaya menulis juga menjadikan umat Islam Indonesia suka berdakwah melalui mimbar secara lisan daripada melalui tulisan. Para daii lebih suka membangkitkan emosi keagamaan dengan retorika daripada membangun nurani dan rasionalitas pemikiran melalui karya-karya ilmiah.

Dengan begitu, setidaknya ada tiga hal yang perlu direnungkan. Pertama, untuk memperdalam ilmu-ilmu keislaman, maka budaya menulis perlu digalakkan mulai dari sekarang, terutama bagi mahasiswa. Kedua, adanya keseimbangan antara dakwah dengan lisan dan dakwah dengan tulisan. Dengan demikian, gerakan dakwah tidak menjadi bersifat temporal, parsial, dan kurang bermakna, dengan tulisan yang mendalam, menyeluruh dan kritis diharapkan akan terlahir generasi muda yang memiliki kesadaran agama yang dilandasi pemahaman keagamaan dan bukan hanya emosi keagamaan. Untuk 
menumbuhkan budaya tulis-menulis ini, kiranya dibutuhkan berbagai kiat dan upaya yang terus-menerus. Dengan demikian, potensi-potensi kepenulisan bisa terus dipacu.

\section{ENDNOTE}

1 Djamalul Abidin, Komunikasi dan Bahasa Dakwah (Jakarta: Gema Insani Press, 1996), hal. 8.

${ }^{2}$ Zlauddin Sardar, Wajah-wajah Islam.

${ }^{3}$ Djujuk Juyoto, Jumalistik Praktis Sarana Penggerakan Lapangan Kerja Raksasa(Yogyakarta: Nurcahaya, 1984), hal. 15.

${ }^{4}$ Di dalam al-Quran kata "pena" secara eksplisit hanya disebutkan tiga kali; (1) pada Surat al-Alaq, (2) kata pena (qalam) dalam surat yang diberi nama al-Qalam yang dibuka dengan huruf nun, dan (3) kata pena qalam yang terdapat dalam Surat al-Luqman : 27.

${ }^{5} \mathrm{Ibid}$.

${ }^{6}$ Al-Quran secara keseluruhan sebenamya telah selesai ditulis pada masa Rasulullah masih hidup, hanya saja ayat-ayat al-Qur'an itu masih terpisah. Orang yang pertama menghimpun al-Quran sesuai dengan kehendak Rasulullah adalah Adalah Abu Bakar Ash Shiddiq. Baca Subhi AshShalih, Membahas IImu-ilmu al-Quran (Jakarta: Pustaka Firdaus, 1992), hal. 84.

7 Ircham Mc., Cara Mudah Menulis IImiah Populer dan Artikel Lainnya(Yogyakarta: Fimaya,1985), hal. 6.

${ }^{8}$ Sanapiah Faisal, Dasar dan Teknik Penelitan Keilmuan Sosial (Surabaya: Usaha Nasional, 1981), hal. 5-50.

${ }_{9}$ Tulisan popular adalah sebuah artikel bukan makalah, yang isinya berlembar-lembar. Artikel ini pun memiliki bermacam-macam jenis, misalnya artikel laporan pengalaman, atikel tumbuh-tumbuhan atau binatang, artikel kesehatan, agama, dan lainnya. Yang terpenting dalam sebuah penulisan ilmiah popular adalah harus menjawab mengapa dan bagaimana permasalahan yang ditulis itu dapat dikemukakan. Baca Ircham Mc., Cara Mudah, hal. 7.

${ }^{10}$ Slamet Suseno, Teknik Penulisan Ilmiah Populer (Jakarta: Gramedia, 1993), hal. 8.

${ }^{11} \mathrm{KMSI}$, Kiat Menembus Kolom dan Media Massa, Artikel, Cerpen, Resensi, dan Puisi(Yogyakarta: Kumia Kalam Semesta, 1995), hal. 20.

${ }^{12}$ Nilai-nilai yang absolute itu sangat sedikitjumlahnya, dalam persentase dapat disebutkan, yakni kurang lebih hanya 5 persen saja dari ajaran Islam. Ajaran-ajaran Islam ini terdapat dalam al-Qur'an dan Hadis Mutawatir.

${ }^{13}$ Bentuk tulisan yang bertujuan mencerdaskan umat ini memiliki kelebihan di bidang pengembangan intelektual. Dengan bentuk tulisan yang menggigit, knits, dan banyak memberikan koreksi maupun kontroversial, maka dialog-dialog intelektual akan semakin subur. Masyarakat akan semakin berani untuk berpikir knitis. Dengan demikian, Islam akan tumbuh subur dan kekayaan intelektual Islam akan semakin besar.

${ }^{14} \mathrm{KMSl}$, Kiat Menembus, hal. 60.

${ }^{15}$ Johnson, Elaine B., Contextual Teaching and Leaming: What is and Why lt's Here To Stay (United States of America: Corwin Press, Inc. 2002), hal. 165.

\section{DAFTAR PUSTAKA}

Abidin, Djamalul. 1996. Komunikasi dan Bahasa Dakwah. Jakarta: Gema Insani Press. Ash-Shalih, Subhi. 1992. Membahas IImu-ilmu Al-Quran. Jakarta: Pustaka Firdaus. Faisal, Sanapiah. 1981. Dasar dan Teknik Penelitian Keilmuan Sosial. Surabaya: Usaha Nasional. Ircham Mc.1985. Cara Mudah Menulis IImiah Populer dan Artikel Lainnya. Yogyakarta: Fimaya. Johnson, Elaine B. 2002. Contextual Teaching and Leaming: What is and why it's here to stay. United States of America: Corwin Press. Juyoto, Djujuk. 1984. Jumalistik Praktis Sarana Penggerakan Lapangan Keja Raksasa. Yogyakarta: Nurcahaya. KMSI. 1995. Kiat Menembus Kolom dan Media Massa, Artikel, Cerpen, Resensi, dan Puisi. Yogyakarta: Kumia Kalam Semesta. Suseno, Slamet. 1993. Teknik Penulisan IImiah Populer. Jakarta: Gramedia. 